\section{Goran Kvrgić ${ }^{1}$}

Dragan Milošević

University Union-Nikola Tesla, Faculty of Management

Goran Ćorić3

Univerrsity Singidunum, Faculty for Business Economics
ORIGINAL SCIENTIFIC ARTICLE

DOI: 10.5937/ekonomika2102035K

Received: October, 29. 2020.

Accepted: January, 17. 2021.

\title{
SMES ECOSYSTEM AND BANKING FINANCE SUPPORT IN SERBIA
}

\begin{abstract}
There is increasing awareness that the current liquidity crisis could lead to a solvency crisis, as many SMEs compensate declining revenues by taking on more debt, often with government support. In 2020 the level of insolvencies and bankruptcies were kept in check, the number of bankruptcies is expected to spike in 2021. This raises the question of efficiency of ecosystem, about policy approaches to support SMEs in need of finance, while not overburdening them with debt, what motivated the authors of the paper to research the banking loans as the access to external sources of finance within the SMEs ecosystem support. Also is analyzed the quality of the sub-dimensions, the legal and regulatory framework, collateralization options, credit information systems and the financial literacy. Descriptive statistical methods, as well as field and desk research, were used in the elaboration of the results. Key results confirmed that SMEs create more lucrative returns to the whole national economy in the improved access to finance if provided with better service models enabled by technology and new propositions as clients - the hypothesis of the research.
\end{abstract}

Key words: SMEs, ecosystem, access to finance, banks, Serbia

JEL classification: G21, L26, M13, O16.

\section{ЕКОСИСТЕМ МЛР И ПОДРШКА ФИНАСИРАҢА БАНАКА У СРБИЈИ}

\begin{abstract}
Апстракт
Јача свест о могућности да би текућа криза ликвидности могла довести до кризе солвентности, јер многа MSP надокнађују своје опадајуие приходе преузимањем вецеге дуга, често уз државну подрику. 2020. године ниво инсолвентности и банкрота је још било могуће контролисати, док се нихово повећање очекује у 2021. години. То поставља питағе ефикасности екосистема и политика подрике MSP којима су потребна у овим околностима финансијска
\end{abstract}

\footnotetext{
${ }^{1}$ goran.kvrgic@famns.edu.rs, ORCID ID / 0000-0002-1261-4590.

${ }^{2}$ dragan.milosevic@famns.edu.rs, ORCID ID/ 0000-0002-5979-2562

${ }^{3}$ gcoric@outlook.com, ORCID ID / 0000-0002-4150-8930
} 
средства која их истовремено не би доводила у додатна дуговања. Ова питаға су мотивисала ауторе да у раду истраже приступ спољним изворима финансирања -банкарским кредитима уоквиру екосистема подршке MSP. Ураду се даље анализира квалитет других димензија, правног и регулаторног оквира, опичје колатерализације, кредитног информационог система и финансијска писменост. У раду су коришиене дескриптивне статистичке методе, као и теренска и деск истраживања. Кључни резултати потврдили су да мала и средња предузеціа стварају уносније приходе изелој нащионалној економији ако им се у квалитетном приступу банкарским изворима финансирања пружају и бољи модели услуга, технолошки напреднији као клијентима-што је и хипотеза овог истражсивања. Скупа регулаиија финансијских тржсишта, неразвијене шеме финансирања или гаранщија које финансира држава, високи парафискални намети могли би, с друге стране, даље нарушити пословни амбијент за пословање малих и средњих предузейа.

Кључне речи: мала и средња предузећа, екосистем подрике, приступ финансијама, банке, Србија

\section{Introduction}

Early evidence suggests that bank lending delayed within the 2020 in many areas of the planet. In some cases, lending volumes even increased to fulfill rising demand from small businesses, as they sought to create up for revenue shortfalls by seizing more debt. Public policies getting to alleviate liquidity constraints have played a vital role during this regard. On the opposite hand, alternative financing instruments are being impacted strongly by the crisis. Specifically, there's concern that sources like early-stage equity and trade finance may dry up as a consequence of the pandemic and related containment measures. Backsliding on the diversification of SME financing instruments, if it materialises, would reverse a positive trend towards achieving a higher balance between bank lending and other financing instruments for SMEs.

Governments and central banks have taken monetary and monetary policy initiatives on an unprecedented scale. Many of the measures have aimed to produce relief to viable, but illiquid companies to limit bankruptcies. These policies were typically delivered during a very short period of your time and were receptive an outsized number of beneficiaries. Given the unexpected nature of the crisis, policy makers have demonstrated flexibility and a willingness to regulate their approaches as implementation proceeded. Continued liquidity support on the present scale entails some risks, particularly for public finances and business dynamics.

Policies going forward are likely to hunt to mitigate these risks. While support programmes are largely receptive all SMEs plagued by the crisis in its immediate aftermath, they will become more targeted to demonstrably viable firms within the next rounds of support. Support may additionally be made increasingly conditional on specific uses of funds, so as to contribute to medium- and long-term policy objectives. 
Aldough, the economy of Serbia performs well within the areas of business support services, public procurement, standards and technical regulations, similarly as in their institutional and regulatory frameworks for SME political opinions, for insolvency, (Reiserer, 2019), the business environment in Serbia continues to be challenged by many factors. The regulation of economic markets which don't allow additional financing sources for SMEs under the higher conditions, the bureaucratic procedure, a nontransparent system of parafiscal charges, the high informal sector.

SMEs in Serbia have staged a gradual recovery from the financial crisis, and as they rebound are looking to speculate. SMEs companies are a awfully important sector within the Serbian economy (Vojteski et al., 2012), with high GVA creation, new jobs and exports results (Simonović et al., 2019). Because the bank lending to SMEs has been flat in recent years, in keeping with the EC Report (EC, 2018) there is room for improvement the financial ecosystem and bank lending access. Traditionally, however, banks have struggled to serve SMEs in an economically sustainable way. SME clients are typical with small levels of income and with needs that fluctuate by maturity, size and industry, and are a various group. It's suggested that leading small business banks can capture twice the most amount revenue per client, and achieve lending product adoption fourfold greater, than their competitors.

Online lenders are adept at driving SMEs demand; however, recent challenges in selling off loan portfolios to banks or investors at expected terms have exposed a weakness in their business models. There's need for leveraging their structural advantages by further digitizing and reinventing the customer experience, learning from attackersfintech companies.

The structure of the paper consists of an introduction, the literature review, main features of the SME sector within the country and the access to finance and quality of the support ecosystem, with the conclusion and references presentation.

\section{Literature review}

The ecosystems are often connected to tech companies like fintech are, but they'll offer to banks to a novel and scalable solution to the competitive challenge. FinTech's offer traditional banking products, bat also many other business services like invoicing, payroll, tax preparation, and inventory management, and with innovative service models that increase income and reduce costs. Banks have great advantages, including rich data and SMEs as customers' trust, to expand beyond their traditional limits into adjacent businesses (Curcic, \& Durkalic, 2019). during this research are outlined some ways how banks can win a big share of SME revenue pools and maximize returns using an innovative ecosystem proposition that addresses the requirements of SMEs (Grozdanic et al., 2012), describing what it takes to achieve an SME ecosystem, what's illustrated within the SMEs ecosystems beyond core banking The ecosystem framework puts particular emphasis on the legal and regulatory aspects for facilitating access to finance for SMEs in Serbia.

The macroeconomic environment, the health of the local financial market and also the overall creditworthiness of enterprises impact are a posh interaction of a range of determinants linked to areas like the access to finance for SMEs (Figure 1). 
Figure 1. SME ecosystem and core banking

\section{Small business ecosystems go beyond core banking}
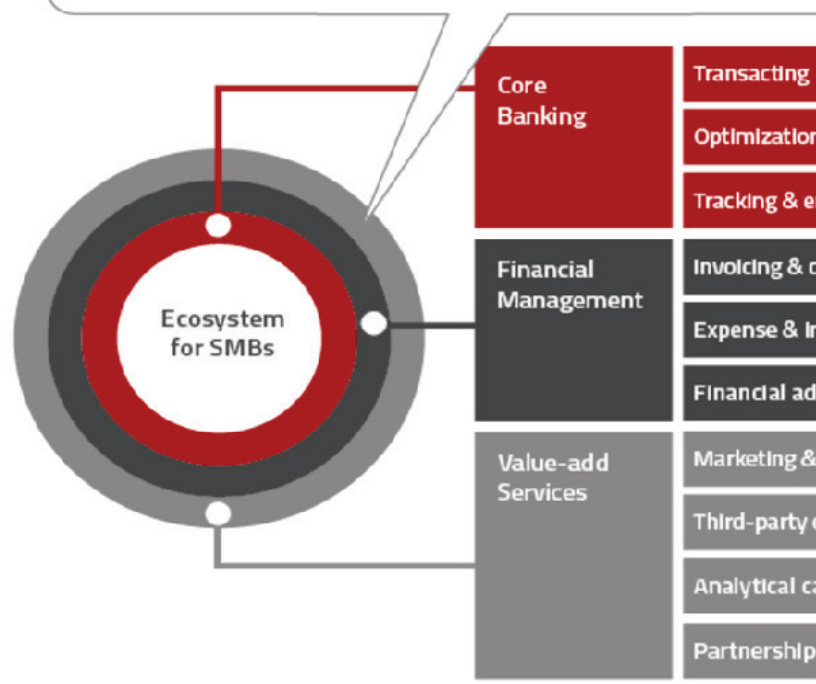

Optimization

Tracking \& error flagging

Invoicing \& collection

Expense \& Inventory management

Financial advice

Marketing \& lead generation

Third-party offerings

Analytical capabilities

Partnership connections

Source: Authors, according to Barua et al., 2019

These are the reasons for permanent improvement of the:

- Legal and regulatory framework which focuses on the legislation facilitating access to finance, including protection of creditor rights, facilitating the employment of collateral and credit information, and banking and exchange regulations, with credit rights, register, credit information bureau, banking regulations, stock market,

- Bank financing, including the lending practices of the Serbian banking market and also the availability of credit guarantees, with the banking lending practices and conditions, credit guarantee schemes, and

- Financial literacy, analyzing government efforts to market financial knowhow among the businessmen and wider population, with planning, design, implementation, monitoring and evaluation (Abreu \& Mendes, 2010; Atkinson, 2017).

\section{SMEs role in Serbian economy}

SMEs with 357234 enterprises hold a dominant place making in Serbian economy, as they hold $99.8 \%$ of the total business population. A majority of $96.2 \%$ are micro-enterprises, small enterprises make $2.96 \%$, medium-sized enterprises $0,66 \%$, and $0.15 \%$ are make up by large enterprises. Serbia has the 50.9, SMEs per inhabitant in 2018 (Serbian Report on SMEs, 
MF, 2018), 66.00\% of total business sector employment, value-added (10 927 million EUR) and $39.25 \%$ of Serbia's exports (Table 1 ).

Table 1. SME sector performance in Serbia, 2017.

\begin{tabular}{|c|c|c|c|c|c|c|c|}
\hline & \multicolumn{2}{|c|}{ Number of enterprises } & \multicolumn{2}{|c|}{ Employment } & \multicolumn{2}{|c|}{$\begin{array}{l}\text { Value-added (EUR } \\
\text { Mill.) }\end{array}$} & \multirow{2}{*}{$\begin{array}{c}\text { Exports } \\
\text { Share }\end{array}$} \\
\hline & No. & Share & No. & Share & No. & Share & \\
\hline SMEs & 357234 & $99.85 \%$ & 873462 & $66.00 \%$ & 10927 & $56.66 \%$ & $39.25 \%$ \\
\hline Micro & 344279 & $96.23 \%$ & 415762 & $31.42 \%$ & 4241 & $21.99 \%$ & $7.95 \%$ \\
\hline Small & 10583 & $2.96 \%$ & 213380 & $16.12 \%$ & 2963 & $15.36 \%$ & $11.05 \%$ \\
\hline Medium & 2372 & $0,66 \%$ & 244320 & $18.46 \%$ & 3723 & $19.30 \%$ & $11.05 \%$ \\
\hline Large & 521 & $0.15 \%$ & 449963 & $34.00 \%$ & 8359 & $43.34 \%$ & $60.75 \%$ \\
\hline
\end{tabular}

Source: Authors, based on World Bank Open Data (database), https://data.worldbank.org.

Looking to the sectoral distribution of SMEs in Serbia, distributive exchange bills for $27.2 \%$ of the full SME population, and $15.5 \%$ of all SMEs in Serbia perform within side the production region (Table 2). The wide variety of SMEs in each sectors has decreased, from $18.0 \%$ to $15.5 \%$ in production, and from $34.0 \%$ to $27.2 \%$ in distributive exchange. Most of SMEs perform in production, exchange region, and offerings in which can be transferring small companies (Ministry of Economy, 2018).

\section{Methodology and findings}

The desk and field research are base methodological tools used for the findings of the paper. Also are used outcomes of OECD, National financial institution and EBRD evaluation and files recommendations. In those analyses and data, the get admission to to finance for SMEs don't forget to be in region in in addition sub-dimensions:

- Within side the felony and regulatory frameworks are determined major improvements,

- Insurance and help to the credit score records of SMEs has been increased via way of means of credit score data systems,

- Subsidized lending to SMEs as public area interventions is found out with slowly transferring closer to credit score guarantees. According to the evaluation because the dominant supply of finance in Serbia for SMEs is financial institution lending (at 43\% of GDP in 2017). Loan situations are normally much less favorable for SMEs, reflecting lenders' perceptions of the chance of default. However, systemic boundaries continue to be in Serbia. (Figure 2). According to the National Bank of Serbia Survey (2020).

New financial institution lending to SMEs multiplied via way of means of $17.2 \%$ wherein loans in overall company loans multiplied to $44.5 \%$ (the inventory of SMEs 
mortgage in 2018 changed into EUR 6.5 billion). Lon-term loans amounted to 77.2 of overall SMEs loans. Lending conditions are improved. SME mortgage programs to overall wide variety of SMEs changed into $14.4 \%$. Rejection charge (SME loans legal/ asked reduced from $28-17.0 \%$ in 2019. Utilization charge of SME loans used/ legal multiplied from ninety to $94.0 \%$ in 2019 . According to the Trading economics (2020) loans to the non-public area averaged 796828.71 RSD million (from 2004 -2020) achieving an all-time excessive of one two hundred 863 RSD million.

Figure 2. Banking loans to SMEs in Serbia, 2019-2020. (RSD Mill.)

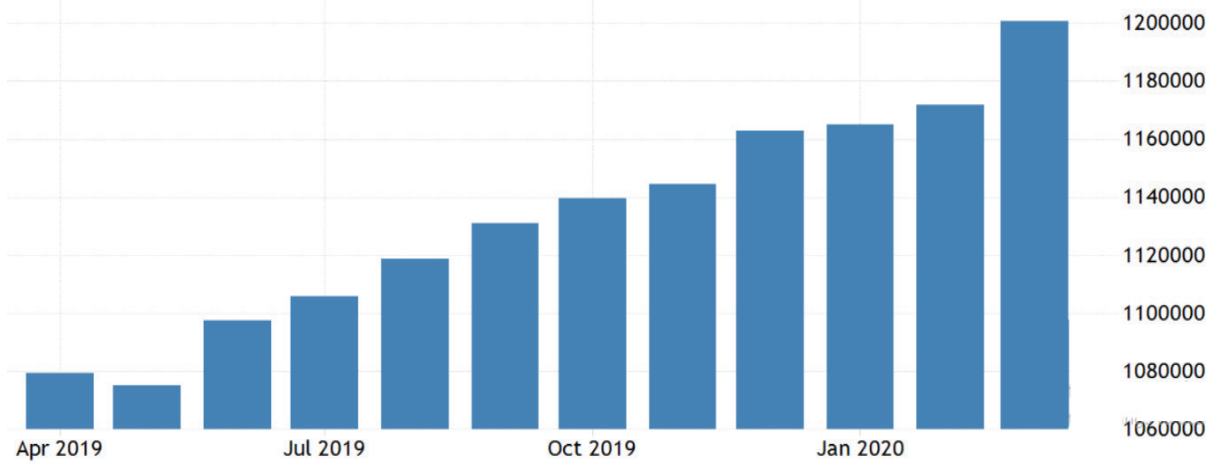

Source: Trading economics, 2020.

SMEs in Serbia in 2017 (EC, 2017), broadly speaking have used small loans as much as 25.000 EUR (37\% of a complete range used loans within side the year), $25 \%$ SMEs - as much as 100.000 EUR, and over million EUR, 9\% of SMEs (Table 2).

Table 2. Serbia, banking loans to SMEs, economic forecasts, 2020-2021.

\begin{tabular}{|l|c|c|}
\hline \multicolumn{1}{|c|}{ Serbia } & 2020 & 2021 \\
\hline Interest Rate (\%) & 1.50 & 1.25 \\
\hline Interbank Rate (\%) & 1.18 & 1.33 \\
\hline Deposit Interest Rate (\%) & 0.50 & 0.75 \\
\hline Lending rate (\%) & 2.50 & 3.5 \\
\hline Loans to Private Sector (RSD Mill) & 1.50 & 1.25 \\
\hline
\end{tabular}

Source: Trading economics, 2020.

The weights used for get entry to to finance size and its sub-dimensions are provided in Table 3. To a rating of 3.72 is classed financial institution lending for SMEs. Relatively excessive rating, or better from in advance years comes from the multiplied macroeconomic balance of the economic system and progressed overall performance of the Serbian banking region In contrast with the international locations. The common rating for the international locations of the Western Balkan location is 5.53. 
Table 3. SMEs access to finance in Serbia, 2019 (1-5 scores)

\begin{tabular}{|l|r|r|r|}
\hline Bank lending & $\begin{array}{r}\text { Weighted } \\
\text { average }\end{array}$ & WB average & Weights \\
\hline 1. Access to finance for SMEs & 3.72 & 3.53 & \\
\hline 1.1 Legal and regulatory framework & 4.38 & 4.14 & $60 \%$ \\
\hline 1.1.1 Creditor rights & 4.27 & 4.20 & $24 \%$ \\
\hline 1.1.2 Registers & 4.45 & 4.58 & $24 \%$ \\
\hline 1.1.3 Credit information bureaus & 5.00 & 4.55 & $24 \%$ \\
\hline 1.1.4 Banking regulations & 4.50 & 3.79 & $14 \%$ \\
\hline 1.1.5 Stock market & 3.29 & 2.93 & $14 \%$ \\
\hline 1.2 Bank financing & 2.80 & 2.67 & $20 \%$ \\
\hline 1.2.1 Banking lending practices and conditions & 3.12 & 3.61 & $60 \%$ \\
\hline 1.2.2 Credit guarantee schemes & 2.33 & 2.30 & $40 \%$ \\
\hline 1.3 Financial literacy & 2.42 & 2.19 & $5 \%$ \\
\hline
\end{tabular}

Source: OECD, 2019.

\section{Discussion}

Bank lending is still the dominant supply of finance for SMEs in Serbia, specializing in SME lending. Systemic troubles stay, as mortgage situations are normally much less favorable for SMEs, reflecting perceived dangers with the aid of using creditors approximately their potential to repay. Government is slowly moving in the direction of greater commercially aligned solutions, however the sponsored lending remains an frequently shape of Public zone interventions. Legal and regulatory framework regarding economic troubles place well-advanced in Serbia. The framework for secured creditors, such as out-of-courtroom docket settlements and courtroom docket strategies seem to have emerge as greater green in current age.

The concrete felony adjustments are but to be visible to boost up enforcement procedures, which stay a bottleneck. Overall banking rules of Serbian are consistent with guidelines of Basel II and Basel III. Legislation and management framework as authorities' coverage response, have a variety of help activities, just like the Strategy for SMEs development improvement. Many authorities' institutions, are worried in the porogramme relate each to economic help: loans, subsidies, improvement of exports help in coming into deliver chains, and non-economic help- education, requalification, expert and consulting assistance.

The part of the assisting SME surroundings are in addition measures:

- The application for help start ups is carried out with the aid of using the Ministry of Economy in cooperation with the improvement Fund of the Republic of Serbia, with overall to be had offers to the belief quantity to 
RSD two hundred millions. Funds below this programme may be used for: upgrade, buy of equipment, everlasting operating capital,

- Programme for captivating entrepreneurship thru help investments meant for buy, of recent or used manufacturing equipment, software, production, everlasting operating capital, as much as $20 \%$ of the overall funding carried out with the aid of using the Ministry of Economy in cooperation with the improvement Fund of the Republic of Serbia,

- Digital transformation help programme, which is carried out with the aid of using Serbian Development Agency, to help SMEs within side the virtual transformation process, as much as $50 \%$ of the eligible expenses at the precept of reimbursement (Jevtic et al., 2020; 2014) The price range of the programme is RSD 70 million, and

- Loans ensures for micro and small felony entities for renovation of contemporary liquidity, funding loans for procurement ok production and upgrading of commercial enterprise facilities, loans of the Agency for Insurance and Financing of Exports (AOFI). The hobby within side the nearby banking device might be in addition induced giant with the aid of using this economic condition.

Foreign exchange risks can pose a specific trouble to the SMEs that are extra unhedged in opposition to them. In 2018 are prioritized overseas alternate-listed loans in new Policy Coordination Instrument Agreement among Serbia and the International Monetary Fund which excessive stage want to be decreased.

The infrastructure round credit score records is solid. A registration gadget with and the cadaster despite the fact that now no longer absolutely to be had online, has been in vicinity for numerous years, and are in large part practical and actively utilized by the nearby banking gadget. A privately run credit score records bureau has been in vicinity on the grounds that 2004, overlaying $100 \%$ of the Serbian grownup population.

Public availability is constrained because of Serbia's specific law that calls for non-public consensus to any credit score search. In 2016 become amended the capital marketplace regulation.

The motive of the regulation become first off to reinforce capital marketplace supervision and decrease dangers of marketplace manipulation, too. However, in addition cognizance constructing is wanted approximately the advantages of capital markets finance, which include a South-East Europe link, to absolutely take advantage of capital marketplace finance possibilities for SMEs. High degrees of non-appearing loans (NPLs) have additionally been decreased systemically.

A plan on NPL (supported through the EBRD, IFC, IMF and the WB), is actively enforcing in Serbia. NPL degrees have fallen (from $20 \%$ in 2015 to under $10 \%$ in 2017). Measures for nearby foreign money lending growing apprehend the dimerization approach awareness with the National Bank of Serbia, collectively with the resilience of the Serbian monetary marketplace. Due to the persevering with erotization of loans, alternate price dangers persist, in particular for smaller businesses.

In addition is established the effect of environment law to average SMEs in Serbia overall performance for the length 2012 to 2020, through summarizing the signs of competitiveness and doing business (Figure 3). 
Figure 3. The impact of ecosystem regulation to overall SMEs in Serbia performance, 2012-2020
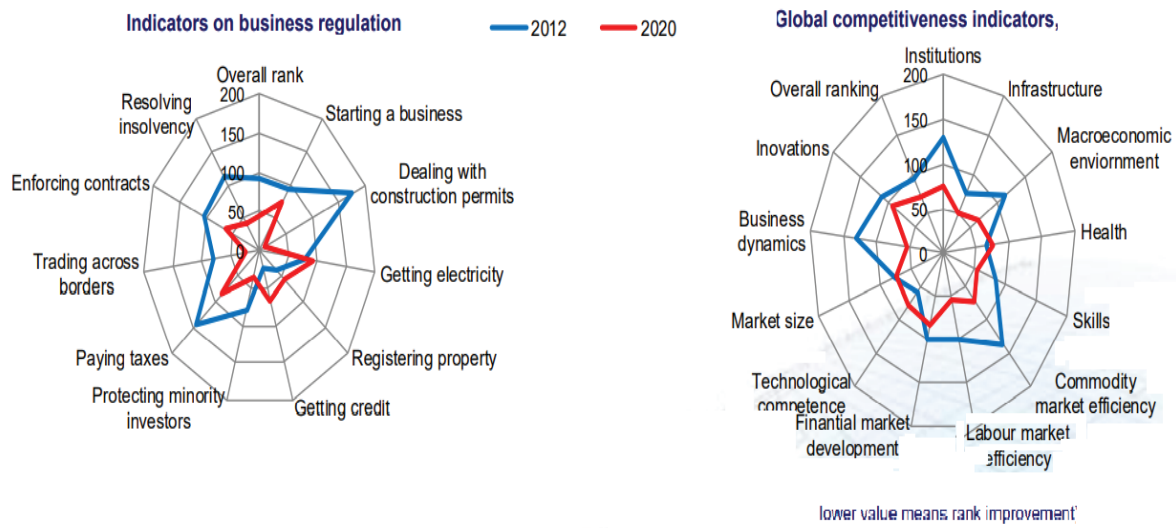

Source: Authors according to WB, WEF data, 2020.

\section{Conclusion}

Banking finance within the SMEs ecosystem support has been researched in this paper. It may be concluded that the get entry to and wider collateralization alternatives are facilitated thru a higher prison and regulatory framework, in addition to the possibility for SMEs to construct a credit score records thru the credit score records structures which insurance expands. The enterprise surroundings in Serbia has been improved.

Public area interventions to ease SME get entry to to finance stays common. Government is slowly moving closer to extra commercially aligned answers along with credit score guarantees, and lending has slowly centred on SMEs, despite the fact that the banking area is in right shape. There isn't clean strategic method to address shortcomings on this area. In leveraging investment thru aid schemes, for SMEs might be essential now no longer to cause them to depending on persevered public finances aid, and purpose a likely risk connected with possible marketplace distortions. Systemically monitored ought to be aid programme and evaluated in opposition to overall performance indicators, to attain the ones SMEs maximum in want of aid and altered as wished (OECD, 2019).

Public area aid might be wished within side the sports of the monetary literacy ranges of SMEs development. Main pointers for the development surroundings situations for SMEs issues on:

- SMEs competitiveness development, via way of means of Government and personal area intensifying their engagement in improving regulatory situations, in reducing red tape,

- Credit assure schemes facilitation in higher get entry to to finance for SMEs,

- The in addition SMEs inclusion into worldwide cost chains and new markets open up,

- The local co-operation increasing via way of means of given the dimensions of Western Balkan economies, supplying resources - as innovation and pleasant infrastructure as a cost-green manner for SMEs to scale up past their home capacities, 
- To assure performance and first-class use of public funds, a scientific assessment of aid programmes for SMEs might need to be an extended run.

Following the developments within side the digitization of the sports, virtual channels are predicted to be an an increasing number of essential approach of engagement among banks and SMEs within side the subsequent 3 to 5 years. The aspiration is extraordinarily straightforward-provide SME clients the goods they need and the Omni channel connection they prefer. Bank executives ought to try and an aspirational goal for SME unit from Serbia, with growing the financial advantages to deliver, accounting for aggressive dynamics and enterprise evolution, and shooting increase throughout all essential dimensions of the SME segment. There might be new investments to innovate alongside those dimensions.

\section{References}

Abreu, M., \& Mendes. V. (2010). Financial literacy and portfolio diversification, Quantitative Finance, 10 (5), 515-528. https://doi. org/10.1080/14697680902878105

Atkinson, A. (2017). Financial education for SMEs and potential entrepreneurs, OECD Working Papers on Finance, Insurance and Private Pensions, No. 43, OECD Publishing, Paris, https://dx.doi.org/10.1787/bb2cd70c-en.

Barua, C., Gati. B., Havas, A., Lajumoke, T., Radnai, M., \& Taraporevala, Z. (2019). How banks can use the ecosystem to win in the SME market, McKinsey.

Durkalic, D., \&Curcic, M. (2019). Međusobni uticaj potraživanja bankarskog sektora i međunarodne investicione pozicije Republike Srbije, Ekonomika 2019, 6(1), 95-106. https://doi.org/10.5937/ekonomika1901095c.

EC. (2018). Proposal for a Council Recommendation on Key Competences for Lifelong Learning, European Commission, Brussels, https://eur-lex.europa.eu/ legalcontent/

EN/TXT/?uri=CELEX\%3A52018DC0024.

EC. (2018). DigComp 2.1: The Digital Competence Framework for Citizens with eight proficiency levels and examples of use, European Commission, Brussels, https://doi.org/10.4018/ijdldc.2019040102.

EC. (2018a). SME Performance Review, European Commission, Brussels, https:// ec.europa.eu/growth/smes/business-friendly-environment/performance-review en (accessed on 30 April 2020).

EC. (2017). Survey on the access to finance of enterprises (SAFE), Analytical Report

EC (2008). Think Small First: A Small Business Act for Europe, Commission of the European Communities, Brussels, available at http://ec.europa.eu/transparency/ regdoc/rep/1/2008/EN/1-2008-394EN-F1-1.Pdf (assessed 12.04.2020).

Grozdanic R., Radovic, M., Kvrgic, G., \& Jevtic, B. (2012). Investment in Innovation of SMEs, Evidence from Balkan Countries, Metalurgia International, 17 (10), 176-179. 
Jevtić, B., Vučeković, M.,\& Radulovic, D.. (2014).Technological innovations: Evidence from Serbia, International Review ISSN: 2217-9739, 2 (3-4), 27-33

Jevtic, B, Zakic, N, Popovic, J, Coric, G. \& G. Kvrgic. 2020. "Digital Challenges for SMES Organisations in Human Capital Investments and Change." In Economic and Social Development, Book of Proceedings. 20--29. https://www. esd-conference.com/upload/book_of_proceedings/_Book_of_Proceedings esdLisbon 2020_Online.pdf

Ministry of Economy (2018). Report on Small and Medium-Sized Enterprises in Serbia for 2017, SME and Entrepreneurship Department, Ministry of Economy, Belgrade. (Accessed on 30 April 2020).

NBS. (2018). Overall Payment System Indicators, National Bank of Serbia, https:// www.nbs.rs/internet/english/35/statistika/index.html (accessed on 14 January 2019).

OECD. (2019). SME Policy Index: Western Balkans and Turkey 2019 - Assessing the Implementation of the Small Business Act for Europe, OECD. https://doi. org/10.1787/051a2e3e-en

OECD. (2018). Financing SMEs and Entrepreneurs 2018: An OECD Scoreboard, OECD Publishing, Paris. https://dx.doi.org/10.1787/fin_sme_ent-2018-en

PPS, NALED, USAID. (2018). (Public-Private Dialogue for Growth), National Alliance for Local Economic Development, Belgrade, http:/www.jpd.rs/ oprojektu.php. (Accessed on 30 April 2020).

Reiserer, A. (2019). Report on conditions for SMEs in Western Balkans, EBRD.

The Republic of Serbia. (2014). Regulation on Rules for State Aid Granting, Ministry of Finance, Republic of Serbia, http://www.mfin.gov.rs/UserFiles/ File/ drzavna\%20pomoc/Uredba\%20o\% 20pravilima \%20za \%20dodelu\%20 drzavne\%20pomoci.pdf. (Accessed on 30 March 2020).

Simonovic, Z., Petrovic, D., \& Curcic, N. (2019). Production of grapes and wine in Serbia, Ekonomika, Niš, 65 (4), 11- 20.

Tradingeconomics. (2020). Loans to the private sector, Serbia, available at https:// tradingeconomics.com/serbia/loans-to-private-sector (visited 12.042020).

Vienna Initiative. (2014). Credit Guarantee Schemes for SME Lending in Central, Eastern and South-Eastern Europe, Vienna Initiative Working Group on Credit Guarantee Schemes., https://doi.org/10.1057/9780230362321.0007

Vojteski-Kljenak, D., Lukic, R., \& Kvrgic, G. (2013). The Inventory Management Efficiency Impact on the Performance of Trade in Serbia, Metalurgia International, 18 (2), 183-189.

World Bank. (2019). World Bank Country and Lending Groups, https://doi. org/10.1596/30977.

World Bank. (2018). Higher but fragile growth, Western Balkans Regular Economic Report, No. 14, World Bank, Washington, DC, http://pubdocs.worldbank.org/ en/194301538650996304/rev2-WBRER14-WQ-web-ENG.pdf (accessed on 15 April 2020). 
World Bank (2018). World Bank Open Data (database), World Bank, https://data. worldbank.org/ (accessed on 19 November 2018).

World Bank. (2018). Doing Business 2019: Training for Reform, World Bank, Washington, DC, http://www.doingbusiness.org/en/doingbusiness.

World Bank. (2018). Global Financial Development Database, https://www. worldbank.org/en/publication/gfdr/data/global-financial-development-database. (Accessed on 20th April 2020).

World Bank. (2016). World Development Indicators 2016, World Bank, Washington, DC... https://doi.org/10.1596/978-1-4648-0683-4. 